TOMASZ STRYJEK

Instytut Studiów Politycznych PAN, Warszawa

\title{
EUROPA ŚRODKOWA (ŚRODKOWO-WSCHODNIA), CZYLI O POCHWALE RÓŻNORODNOŚCI I KOMPARATYSTYKI
}

W historiografii nie używa się pojęć „Europa Środkowa” i „Europa Środkowo-Wschodnia" wobec jednoznacznie określonych jednostek terytorialnych. Odpowiedź na pytanie o ich granice zależy oczywiście od tego, co z przeszłości w perspektywie „długiego trwania” uznamy za istotę środkowo-(wschodnio-)europejskości. Zastanawianie się nad pytaniem, czy można mówić o ciągłym istnieniu Europy Środkowej lub Środkowo-Wschodniej jako regionu o szczególnych cechach gospodarczych, politycznych i kulturowych od czasu jego chrystianizacji i powstania państw dynastycznych w IX-X w. po współczesność w moim przypadku nie zaowocowało pozytywną konkluzją. 0 jego specyfice z pewnością można mówić, jednak w każdej epoce dotyczyła ona innych zjawisk i innego obszaru. Strapionego tą uwagą czytelnika pragnę jednak zapewnić, że nie będę próbował dowieść, iż żadnej z tych Europ nie było i nie ma. Będę starał się natomiast określić, w odniesieniu do jakich epok stosowanie tych pojęć rzeczywiście coś wyjaśnia. Podejmę też krytykę ujęć, w których są one wygodną ramą interpretacyjną „rzutowaną” głęboko wstecz dla nadania sensu dziejom przez współczesnych historyków.

Wspólnym motywem tych, którzy pojęcia „Europy Środkowej” i „Europy Środkowo-Wschodniej" stworzyli i upowszechnili, było dążenie do wyodrębnienia obszaru nigdy wprost nienależącego do Zachodu, niebędącego jednak także częścią (chyba że w wyniku podboju) tego, co z perspektywy okcydentalnej nazywano „Wschodem”- Cesarstwa Bizantyjskiego, państwa mongolskiego i otomańskiego, w końcu imperium rosyjskiego i radzieckiego. Tylko dla części z owych badaczy pojęcia te były - jak 
w przypadku Oskara Haleckiego ${ }^{1}$ - także kategoriami poznania historycznego. Cele niemieckich wizjonerów Europy Środkowej - w latach czterdziestych XIX w. Friedricha Lista, a w czasie I wojny światowej Friedricha Naumanna - były jednoznacznie polityczne. Szło tu mniej o stworzenie perspektyw postępu cywilizacyjnego w krajach nad Wełtawą, Wisłą, Sawą i Dunajem, bardziej natomiast o zbudowanie w strefie historycznego wpływu kultury niemieckiej takiej potęgi, która byłaby zdolna do konkurencji, przede wszystkim gospodarczej, z innymi imperiami ${ }^{2}$. U późniejszych zwolenników postrzegania dziejów Europy przez pryzmat tych pojęć, reprezentujących kraje na wschód od Niemiec, cel polityczny także nie był jedyny, ale często wybijał się na pierwszy plan i zależał od tego, jak postrzegali oni sytuację międzynarodową. Były to zatem bardziej projekty kształtowania tożsamości regionalnej, mające na celu historyczną legitymizację współczesnych dążeń krajów położonych w geograficznym środku kontynentu, niż koncepty skonstruowane dla poznania dziejów pewnej części Europy. W XX w. rodziły się one głównie z poczucia zagrożenia bezpieczeństwa państw narodowych, które od 1918 r. stały się samodzielnymi uczestnikami stosunków międzynarodowych. U schyłku I wojny światowej i tuż po niej chodziło o zaznaczenie ich pełnoprawnego miejsca na mapie politycznej Europy ${ }^{3}$, w latach trzydziestych o wyrwanie się z opresji położenia między Niemcami a ZSRR, w siedemdziesiątych i osiemdziesiątych o przełamanie klątwy jałtańskiego podziału kontynentu ${ }^{4}$, w końcu w ostatniej dekadzie stulecia o pełnoprawne członkostwo w Unii Europejskiej i Organizacji Paktu Północnoatlantyckiego (NATO). Dla każdego z tych postulatów szukano uzasadnienia, które miało dowodzić historycznej europejskości ziem położonych na wschód od Łaby, Alp i Adriatyku oraz na południe od Półwyspu Skandynawskiego. Żadna z granic regionu środkowo-(wschodnio-)europejskiego nie została przyjęta bez kontrowersji i sporów. Jednak największe wątpliwości zawsze dotyczyły pytania, gdzie kończy się „środek” i zaczyna „wschód” Europy.

W projektach powstałych w XX w. środkowo-(wschodnio-)europejskość miała zatem oznaczać uczestnictwo w regionalnej tożsamości wspólnoty identyfikującej się z dziedzictwem historycznym ziem rozumianych jako „wschodnie kresy Zachodu”. Od okresu międzywojennego, gdy kwestię wyodrębnienia tej części Europy dyskutowano już na międzynarodo-

\footnotetext{
${ }^{1}$ Zob. O. Halecki, Historia Europy - jej granice i podziały, Lublin 2002 (oryg. ang. 1950).

${ }^{2}$ F. List, Das nationale System der politischen Ökonomie, Stuttgart 1841; F. Naumann, Mitteleuropa, Berlin 1915.

${ }^{3}$ T. Garrigue Masaryk, Nová Evropa. Stanovisko slovanské, Praha 1920.

${ }^{4}$ M. Kundera, Zachód porwany albo tragedia Europy Środkowej, ,Zeszyty Literackie” 1984, 5, s. 14-31 (oryg. ang. 1984).
} 
wych kongresach historycznych ${ }^{5}$, po współczesność aspekt tożsamościowy odgrywał dużą rolę nie tylko u polityków czy publicystów, ale także u historyków. Nie przypadkiem historiografie Polski, Czech i Węgier - krajów znajdujących się w centrum wszystkich konceptów „środka Europy" - właśnie na przełomie XX i XXI w. zaowocowały wydaniem syntez ujmujących dzieje własnego narodu w takiej perspektywie regionalnej.Jak się wydaje, autorzy i redaktorzy tych prac (Jerzy Kłoczowski, Jan Křen, László Kontler) ${ }^{6}$, decydując o ich przedmiocie, wzięli pod uwagę nie tylko wspólną przeszłość pewnych krajów, ale także przyszłość, czyli to, jakie w tym momencie miały one perspektywy członkostwa w UE. Do syntezy pod redakcją Kłoczowskiego (2000) włączono dzieje Ukrainy i Białorusi od XIV w. do współczesności. Czyżby uznano, iż pozostawanie przez nie w związkach historycznych z Polską i Litwą daje podstawy do tego, aby współcześnie one także uczestniczyły w procesie akcesyjnym? Z kolei J. Křen do krajów wchodzących do tego regionu nie włączył Chorwacji, choć podobnie jak Austria, Węgry, Czechy, Słowacja, Słowenia i część Polski wchodziła ona w XVIII-XIX w. w skład monarchii habsburskiej, a i w poprzednich stuleciach dzieliła z nimi szereg doświadczeń politycznych i cech kulturowych. Czyżby na decyzji tej zaważył fakt, iż w chwili przygotowywania dzieła (do 2005) nie osiągnęła ona jeszcze, po wojnie w latach 1991-1995 i rządach Franjo Tuđmana, standardów skonsolidowanej demokracji, zatem perspektywa jej członkostwa w UE wydawała się odległa? Jeśli tak było, to postępowanie tych autorów stanowiłoby świetną ilustrację tezy, iż w historiografii zajmującej się przeszłością wielkich zbiorowości terytorialnych bardzo trudno o uniknięcie podejścia teleologicznego.

$\mathrm{Z}$ pewnością $\mathrm{w}$ przeszłości ziem położonych geograficznie w centrum kontynentu było wiele doświadczeń wspólnych czy podobnych, poszczególne wydarzenia czy zjawiska historyczne zasługują zatem na to, by być przedmiotem osobnych opracowań. W każdej epoce wspólne doświadczenia dotyczyły jednak innej grupy krajów. Już północna granica panowania starożytnego Rzymu „przecinała” w istocie na pół terytoria zaliczone w XX w. do szerokiej wersji regionu środkowo-(wschodnio-)europejskiego, czyli ziem położonych między Bałtykiem, Adriatykiem, Morzem Egejskim i Morzem Czarnym. Następnie wyraźnie szerszy był zakres występowania prawa niemieckiego $\mathrm{w}$ miastach i wsiach w późnym średniowieczu

${ }^{5}$ Zob. J. Kłoczowski, Europa Środkowowschodnia w historiografii krajów regionu, Lublin 1993.

${ }^{6}$ Historia Europy Środkowo-Wschodniej, t. 1-2, red. J. Kłoczowski, Lublin 2000; J. Křen, Dvě století střední Evropy, Praha 2005; L. Kontler, A History of Hungary. A Millenium in Central Europe, New York 2002. 
i nowożytności niż przeprowadzonej wcześniej chrystianizacji w obrządku łacińskim. Na terytorium większym, niż określone przez występowanie tych dwu zjawisk, a także niż najszersze ujęcia regionu, w XV-XVI w. ustaliła się poddańcza, inna niż na Zachodzie, sytuacja prawna chłopów. Następnie jednak nie w całej Europie Wschodniej - tak w historiografii zachodniej określa się tę część kontynentu, w której aż do XIX w. właściciele ziemi korzystali w rolnictwie $\mathrm{z}$ darmowej siły roboczej - ale jedynie w jej nadbałtyckiej części ukształtowała się gospodarka folwarczna powiązana z rynkiem zachodnim. Z kolei w drugiej połowie XIX w. nierówne tempo industrializacji wyraźniej niż dotychczas zróżnicowało poziom rozwoju gospodarczego krajów zaliczanych do regionu, przyczyniając się do wyprzedzenia pozostałych przez Czechy, Śląsk i Austrię. Wtedy także okazało się, że między narodami Europy Środkowej (Środkowo-Wschodniej) występują konflikty o terytoria, których nie można rozwiązać inaczej niż przez walkę zbrojną. W związku z tym w XX w. państwa i narody tej części Europy wzięły udział po przeciwnych stronach w obu wojnach światowych. Politycznie zjednoczone po raz pierwszy zostały dopiero w czasie trzeciego wielkiego konfliktu w tym stuleciu - zimnej wojny. Współcześnie większość z nich weszła w związek polityczny i gospodarczy przez uczestnictwo w UE i NATO. Co więcej, dzięki członkostwu w tych organizacjach stały się one pełnoprawnie częścią Zachodu, wobec którego od stuleci określały się tożsamościowo.

Europa Środkowa (Środkowo-Wschodnia) w historiografii - zrealizowany projekt

tożsamościowy

Wybranie i usytuowanie na pierwszym planie procesu historycznego tych zjawisk, które miały charakter „endemiczny” i występowały z różną intensywnością, ale w każdej części - na całym obszarze Europy Środkowej (Środkowo-Wschodniej), nastręczało wyjątkowych trudności historykom, dążącym do przygotowania syntez obejmujących całe ostatnie tysiąclecie dziejów. Pomysłów wyznaczenia granic regionu było niemal tyle, ilu mierzących się z tym wyzwaniem autorów. Od wersji obejmującej jedynie Polskę, Czechy i Węgry jako jego „twardy rdzeń" (Piotr S. Wandycz) ${ }^{7}$ przez wersję środkowoeuropejską, skoncentrowaną na dziejach krajów należących do monarchii habsburskiej (ale tylko w XIX i XX w. - J. Křen) i środkowo-wschodnioeuropejską,

${ }^{7}$ P. S. Wandycz, Cena wolności. Historia Europy Środkowo-Wschodniej od średniowiecza do współczesności, Kraków 1995 (oryg. ang. 1992). 
w której historię królestw założonych przez Piastów, Przemyślidów i Arpadów powiązano z historią ziem wchodzących w skład Wielkiego Księstwa Litewskiego i Rzeczypospolitej Obojga Narodów (J. Kłoczowski) ${ }^{8}$ po wersję autorów amerykańskich, dotyczącą obszaru położonego między wspomnianymi czterema morzami, zaplanowaną w latach siedemdziesiątych XX w. wobec zimnowojennego podziału kontynentu i funkcjonującego wtedy na Zachodzie pojęcia „Europy Wschodniej”.

Paradoksalnie najmniej zastrzeżeń co do koncepcji regionu wywołuje ostatnia, czyli ta, która odnosi się do największego obszaru. Jej autorzy za punkt wyjścia wprost przyjęli współczesną im sytuację polityczną. Wydaje się, że autorzy pozostałych ujęć, określając granice przedmiotu zainteresowania, także znaleźli się w „pułapce teleologicznej”, jednak albo sobie tego nie uświadomili, albo nie zostało to przez nich ujawnione. Dążyli do nadania dziejom wybranego obszaru dużej spójności, akcentowali także jego odrębność wobec innych regionów, przez to jednak ich wysiłki nie stały się bardziej przekonujące. Tendencje te widać wyraźnie zarówno w pracy P. Wandycza, jak w opracowaniu pod redakcją J. Kłoczowskiego. Porównajmy sposób rozumowania autorów tej ostatniej oraz uczestników projektu amerykańskiego, są to bowiem dwa największe zbiorowe opracowania dziejów regionu, reprezentujące ambicje całościowe.

W projekcie ,amerykańskim” za region Europy Środkowo-Wschodniej uznano te państwa, które po 1945 r. zachowały formalną suwerenność, lecz stały się komunistyczne i przynajmniej przez pewien czas należały do radzieckiej strefy wpływu (zatem także Jugosławię i Albanię). Ta koncepcja była najbliższa rozumieniu Europy Środkowo-Wschodniej przez O. Haleckiego z 1950 r. ${ }^{10}$, odnoszącemu się do całości ziem między Niemcami i Austrią (Europą Środkowo-Zachodnią) a Rosją (Eurazją), aczkolwiek nie była z nim tożsama. Dzieje krajów bałtyckich oraz Białorusi i Ukrainy włączono do tego opracowania tylko w okresach, co do

${ }^{8}$ Różnica między ujęciami Křena i Kłoczowskiego pozostaje charakterystyczna dla czeskiej i polskiej refleksji nad granicami „środka” Europy. W obu krajach Czechy i Polskę traktuje się jako należące do regionu, uwaga skierowana jest jednak w innym kierunku. W pierwszym ku regionowi naddunajskiemu, w drugim ku wschodowi. W Czechach prowadzi to do utożsamiania Europy Środkowej z krajami monarchii habsburskiej,w Polsce do utożsamiania Europy Środkowo-Wschodniej z terytorium Rzeczypospolitej Obojga Narodów. O tej różnicy oraz o znaczeniu mitu kresowego w Polsce dla współczesnego myślenia o regionie zob. A. F. Kola, Europa w dyskursie polskim, czeskim i chorwackim. Rekonfiguracje krytyczne, Toruń 2011, s. 61-103.

${ }_{9}$ A History of East Central Europe, red. P.F. Sugar, D. W. Treadgold, Seattle-London 1974-2001, t. 1-5. Opis serii zob. 〈http://www.washington.edu/uwpress/books/ series/Serieshece.html> (dostęp: 31 I 2013). Serię zaplanowano pierwotnie na dziesięć tomów, ale epoki przed ok. 1000 r. (t. 2) oraz po 1939 r. (t. 10) do dziś nie opracowano.

${ }^{10}$ O. Halecki, op. cit., s. 121-136. 
których uznano, że więcej je wiązało z Europą Środkową niż Północną (Skandynawia) i Wschodnią (Rosja). Jednocześnie przeciwną decyzję podjęto wobec krajów bałkańskich przez kilka stuleci należących do państwa otomańskiego. Projekt ten obejmował zatem na przestrzeni całego ostatniego tysiąclecia obszar skądinąd nazywany „Europą Południowo-Wschodnią". W dwu punktach - częściowego wyłączenia krajów bałtyckich, Białorusi, Ukrainy i Mołdawii oraz pełnego włączenia Bałkanów - różnił się od syntezy pod redakcją J. Kłoczowskiego, która w ogóle nie dotyczyła ziem położonych po południowej stronie granicy wyznaczonej przez dolny Dunaj i Sawę. Projekt autorów amerykańskich zakwestionował znaczenie kryterium przynależności do Kościoła łacińskiego (ewentualnie także Kościołów unickich), odgrywającego istotną rolę we wcześniejszej dyskusji nad granicami omawianego regionu. Wiele miejsca poświęcono w nim krajom bałkańskim, które w XIX i XX w. swą własną sytuację wobec nowoczesności rozpatrywały w perspektywie okcydentalizacji, a nie - jak Czechy, Węgry i Polska - w prostszej, bo niewymagającej „przekroczenia” granicy cywilizacyjnej, perspektywie modernizacji peryferii pozostających w przeszłości w stałym kontakcie z Zachodem.

Polityczny kontekst takiego określenia granic Europy Środkowo-Wschodniej w opracowaniu historyków amerykańskich był nie mniej wyraźny niż w przypadku syntez, które stworzyli autorzy reprezentujący kraje zaliczane do regionu. Jednak efekt tego przedsięwzięcia nie nosi wyraźnych cech projektu tożsamościowego, co różni go od opracowania zespołu kierowanego przez J. Kłoczowskiego. Najdobitniej uwydatnia się to w odniesieniu do Wschodu. I jedni, i drudzy „pozostawili” Rosję na zewnątrz wybranego obszaru, jednak tylko autorzy amerykańscy uznali, iż dzieje Rusi w średniowieczu należały do regionu Europy Wschodniej, dzieje zaś ówczesnej Litwy, Prus i Inflant zaliczyli do regionu północnoeuropejskiego. Podobną decyzję podjęli względem należących do Rosji w XIX w. ziem ruskich dawnej Rzeczypospolitej Obojga Narodów i Inflant - włączyli je do opracowania w takim zakresie, w jakim w okresie 1795-1918 r. na ich obszarze występowały przejawy opozycyjnych wobec caratu dążeń politycznych (powstania polskie, nowoczesne ruchy narodowe od lat dziewięćdziesiątych XIX w.). Konsekwentnie uwzględnili natomiast historię niepodległej Litwy, Łotwy i Estonii w okresie międzywojennym. W końcu dzieje Grecji wprowadzili do opracowania w epokach, w których pozostawała ona pod wspólną władzą z innymi krajami bałkańskimi, tj. w imperium otomańskim oraz w okresie walki przeciw niemu o ustanowienie niepodległych państw w XIX w.

Jak się wydaje, twórcy projektu „amerykańskiego” już we wstępnym założeniu przyjęli, iż spójności temu przedsięwzięciu nie da się zapew- 
nić. Tu każdy z autorów ośmiu tomów, wydanych na przestrzeni dwudziestu kilku lat (1974-2001), wziął na siebie odpowiedzialność wyłącznie za własną interpretację, a nie za to, jak komponuje się ona z pozostałymi. Większość z nich opracowała w istocie dzieje poszczególnych państw czy obszarów należących do kilku państw, ale połączonych w pewnych okresach wspólnymi dążeniami politycznymi: Rzeczypospolitej Obojga Narodów (1386-1795) ${ }^{11}$, jej ziem pod zaborami (1795-1918) ${ }^{12}$, ziem państwa Habsburgów poza samą Austrią (1526-1918) ${ }^{13}$ oraz krajów bałkańskich w epoce podległości Porcie Otomańskiej (1354-1804) ${ }^{14}$ i wyzwalania się spod zależności od niej (1804-1920) ${ }^{15}$.

Jedyne trzy tomy tej serii, które odnoszą się do całego regionu, to opracowania początkowej i końcowej fazy jego dziejów - lat 1000-1500 i 19181939 - oraz atlas historyczny ${ }^{16}$. Autor pierwszego z nich, mediewista Jean W. Sedlar, konsekwentnie trzymał się układu nie chronologicznego, lecz problemowego. Wykład historii polityczno-militarnej (stosunków międzypaństwowych) ograniczył do minimum i umieścił nie na począt$\mathrm{ku}$ - gdzie, jak to w syntezach tego typu często bywa, odegrałby on rolę osi chronologicznej i ramy terytorialnej oraz określił granice przedmiotu całego opracowania - lecz w końcowej partii dzieła. Pracy tej nie towarzyszy założenie, iż region Europy Środkowo-Wschodniej ukształtował się wraz z powstaniem w IX-X w. kilku dynastycznych ośrodków władzy na wschód od dawnego imperium karolińskiego, zatem zadaniem autora (a także autorów następnych tomów) jest śledzenie jego losów aż do dnia dzisiejszego. Praca J. Sedlara zawiera natomiast panoramę różnych zjawisk politycznych, gospodarczych i kulturowych występujących w średniowieczu na obszarze wyodrębnionym nie przez ówczesne, lecz późniejsze wspólne doświadczenia historyczne - autor przyznał wprost, iż jego poszczególnych części w interesującej go epoce wiele nie łączyło. Wymienił jedynie dwie specyficzne cechy całej historii Europy Środkowo-Wschodniej - upadek tutejszych monarchii w XIV-XVIII w.i podporządkowanie ich władzy imperiów z centrami położonymi poza granicami regionu (Stambuł, Wiedeń, Petersburg, Berlin) oraz rządy komunistyczne i fakt zależności od

11 D.Z. Stone, The Polish-Lithuanian State 1386-1795, Seattle-London 2001 (t. 4).

12 P. S. Wandycz, The Lands of Partitioned Poland 1795-1918, Seattle-London 1975 (t. 7 , wyd. pol. Pod zaborami. Ziemie Rzeczypospolitej w latach 1795-1918, Warszawa 1994).

${ }_{13}$ R. A. Kann, Z. V. David, The peoples of the eastern Habsburg lands 1526-1918, Seattle-London 1984 (t. 6).

${ }^{14}$ P.F. Sugar, Southeastern Europe under Ottoman Rule 1354-1804, Seattle-London 1977 (t. 5).

${ }^{15}$ Ch. i B. Jelavich, The Establishment of the Balkan National States 1804-1920, SeattleLondon 1977 (t. 8).

${ }^{16}$ P. R. Magocsi, Historical Atlas of the Central Europe, Seattle-London 2002 (t. 1). 
ZSRR od 1945 r. ${ }^{17}$ I on, i Peter F. Sugar oraz Donald W. Treadgold, redaktorzy całej serii, osobne opracowanie całości dziejów tej części świata uzasadnili nie potrzebą oddania ich istotowości czy unikalności, lecz tym, iż wiedza o nich jest bardzo słabo reprezentowana w zachodnich syntezach dziejów Europy, a także tym, że historiografie krajów regionu mają skłonność do koncentracji na historii narodowej ${ }^{18}$.

Konstrukcja projektu amerykańskiego, zgodnie z którą okres od początku unii polsko-litewskiej (1386), podboju Bałkanów przez Osmanów (XV w.) i zwycięstwa Habsburgów w rywalizacji z Jagiellonami o Czechy i Węgry (1526) po I wojnę światową przedstawiono nie integralnie, lecz w ramach poszczególnych państw, nie wynikała jedynie z ograniczonego zakresu kompetencji poszczególnych autorów. Po pierwsze, podległość ziem Europy Środkowo-Wschodniej w XV-XVIII w. centrom władzy w Wiedniu, Stambule i Krakowie (Warszawie), a w epoce od rozbiorów Rzeczypospolitej także w Berlinie i Petersburgu, bardziej sprzyjała wzajemnemu oddalaniu się od siebie, niż zbliżaniu dróg ich rozwoju. Występowały liczne różnice gospodarcze, ustrojowe, administracyjne i wyznaniowe, a ówczesne wyobrażenia ich ludności o sobie nawzajem kształtowały się przede wszystkich pod wpływem stałej rywalizacji i wojen między nimi. Po drugie, ani elity, ani tym bardziej niższe warstwy społeczne państw, które od Bułgarii po Rzeczpospolitą utraciły suwerenność na rzecz „zewnętrznych” ośrodków władzy od XIV do XVIII w., nie postrzegały tego doświadczenia jako wspólnej niewoli. Uwzględniając to, że wymienione czynniki bardziej dzieliły, niż łączyły, należałoby przyjąć, iż o powstaniu Europy Środkowo-Wschodniej w znaczeniu używanym przez autorów amerykańskich można mówić nie wcześniej niż od zawiązania się solidarności między przywódcami ruchów narodowych skierowanych przeciw monarchiom Świętego Przymierza oraz Turcji w dobie Wiosny Ludów.

Tezę, że w wymiarze tożsamościowym region ten kształtował się „dopiero” od połowy XIX w., a na arenie międzynarodowej wyraźniej zaświadczył o swym istnieniu w okresie międzywojennym, potwierdza ostatni tom wydania amerykańskiego autorstwa Josepha Rothschilda. Przedstawił on lata 1918-1939 w tradycyjnym ujęciu - poświęcił osobne rozdziały poszczególnym krajom od Albanii po państwa bałtyckie. W poprzedzającym je wprowadzeniu zawarł jednak charakterystykę wspólnych wyzwań zewnętrznych (przetrwanie między Niemcami i Włochami a ZSRR) oraz wewnętrznych (utrzymanie spójności, modernizacja),

${ }^{17}$ J.W. Sedlar, East Central Europe in the Middle Ages 1000-1500, Seattle-London 1994 (t. 3), s. X-XI.

${ }^{18}$ Ibidem, s. VII. 
wyodrębniających je z całości kontynentu ${ }^{19}$. Odpowiedziom tutejszych elit i rządów na te wyzwania towarzyszyła już wówczas świadomość wspólnego położenia. Toteż $\mathrm{w}$ rządzeniu państwem sięgały one po podobne środki: wzmocnienie władzy wykonawczej i centralizacja (autorytaryzm), przejmowanie niektórych wzorów mobilizacji politycznej od państw faszystowskich i asymilacja mniejszości narodowych, tendencje do nacjonalizmu gospodarczego i próby reform rolnych. Po podobne sposoby rozwiązania podobnych problemów wewnętrznych sięgnęły wówczas także rządy Hiszpanii i Portugalii,jednak ich sytuacja była o tyle odmienna, że nieprzerwanie były one uczestnikami polityki europejskiej od średniowiecza, a także nie czuły zagrożenia dla swej suwerenności ani ze strony ZSRR, ani państw rewizjonistycznych.

Ostatecznie amerykańska koncepcja historii Europy Środkowo-Wschodniej przekonuje do myślenia o tej części świata jako o regionie charakteryzującym się swoistym doświadczeniem dziejowym właściwie jedynie odnośnie do okresu, na którym się kończy - lat 1918-1939 (dotyczyłoby to także okresu po 1939 r., gdyby uczestnicy tego projektu go opracowali). Jeśli chodzi o epoki wcześniejsze, to dla czytelników anglojęzycznych odgrywa ona natomiast rolę kompendium wiedzy o przeszłości krajów, które łączy głównie to, że są marginalnie traktowane w opracowaniach historii powszechnej. Wydaje się, że świadomość teleologicznego charakteru przedsięwzięcia, które zaczęto realizować w latach siedemdziesiątych, zatem w czasach jałtańskiego podziału Europy, towarzyszyła autorom od początku. Na jej pogłębienie mógł też dodatkowo wpłynąć fakt politycznego rozpadu regionu w latach 1989-1991, z pewnością dwie dekady wcześniej nieoczekiwany.

Inny zamiar powzięli natomiast autorzy składającego się z dwu tomów i poprzedzonego dotyczącym całości wprowadzeniem projektu "lubelskiego" 20 . Historycy polscy i z Polską związani przygotowali integralne ujęcia dziejów całości ziem Europy Środkowo-Wschodniej od pojawienia się Słowian na arenie dziejowej do początku XIV w. (Henryk Samsonowicz), w stuleciach od XIV do XVII (J. Kłoczowski) oraz w XX w. (P. Wandycz). Ci trzej główni twórcy dzieła, wsparci przez autorów francuskich oraz polskich, specjalistów od historii poszczególnych państw (Daniel Beauvois - Rzeczpospolita w XVIII-XIX w., Marie-Elizabeth Ducreux - monarchia habsburska w tej epoce) i tematów, w pierwszym tomie przedstawili generalną ramę chronologii dziejów regionu, w drugim zaś zamieścili opracowania niektórych zagadnień szczegółowych.

${ }^{19}$ J. Rothschild, East Central Europe between the Two World Wars, Seattle-London 1974 (t. 9), s. 3-26.

${ }^{20}$ Historia Europy Środkowo-Wschodniej. 
Podstawą wyodrębnienia regionu - który zdaniem H. Samsonowicza miał powstać już w X w. - jest zawiązanie się trzech dynastycznych ośrodków władzy (Praga, Buda, Gniezno) i przyjęcie przez nie chrztu w obrządku łacińskim ${ }^{21}$. Umacnianie więzi tych ziem z Zachodem i wprowadzanie w orbitę oddziaływania cywilizacji łacińskiej kolejnych obszarów na wschodzie i nad Bałtykiem stanowi w istocie oś konstrukcyjną narracji. W odniesieniu do epoki opisanej przez H. Samsonowicza, gdy państwa Piastów, Przemyślidów i Arpadów z jednej i państwo Rurykowiczów z drugiej strony orientowały się na odmienne centra cywilizacyjne, a stosunki między nimi nie były bardziej intensywne niż między jakimikolwiek innymi dynastiami w Europie, prowadzi to do konfuzji terminologicznej. Autor ten raz to używa terminu „Europa Środkowo-Wschodnia”, wtedy, gdy chce podkreślić związki Rusi z zachodnimi sąsiadami, raz to „Europa Środkowa”, wtedy gdy rzecz dotyczy wyłącznie tych ostatnich ${ }^{22}$.Zważając na to, że związki te były wtedy jeszcze słabe, a takie procesy gospodarczo-społeczne, jak kolonizacja na prawie niemieckim i kształtowanie się stanów dotyczyły wyłącznie Polski, Czech i Węgier, termin „Europa Środkowa” (o ile w ogóle miałby być stosowany) byłby bardziej adekwatny dla całego okresu opracowanego przez tego wybitnego mediewistę w omawianym dziele ${ }^{23}$.

Tożsamościowy aspekt dzieła wyraża się najwyraźniej w rozdziałach opracowanych przez J. Kłoczowskiego. Silnie akcentuje on dobrowolny i kontraktowy charakter rozwiązań służących rozwojowi terytorialnemu tutejszych państw - przede wszystkim związku Polski i Litwy. Przekonuje, iż dzieje tej unii powinny stanowić przedmiot szczególnego zainteresowania jako doświadczenie poprzedzające współczesny projekt integracyjny UE. Wprost traktuje współczesną Białoruś, Litwę, Polskę i Ukrainę jako „państwa sukcesyjne dawnej Rzeczypospolitej” ${ }^{24}$. Podnosi także zna-

${ }^{21}$ Zob. H. Samsonowicz, Powstanie Europy Środkowo-Wschodniej i Nowy porządek społeczny i polityczny, w: Historia Europy Środkowo-Wschodniej, t. 1, s. 35-54.

${ }^{22}$ Zob. np. ibidem, s. 53.

${ }^{23}$ Zob. ibidem, s. 66-76.

${ }^{24}$ Zob. J. Kłoczowski, Unia polsko-litewska, w: Historia Europy Środkowo-Wschodniej, t. 2, s. 80. Esej o tym, jak owa interpretacja dziejów tych czterech państw wchodzi na współczesnej Ukrainie w rywalizację z perspektywą umieszczającą historię tego kraju wyłącznie w ramach dziejów Rusi i Rosji, napisał Andrij Portnow (Andrìj Portnov) Koncept Central'noï Êvropi ta Rič Pospolita âk proobraz êvropejs'koï spilnoti, w: idem, Mìz „Central'noû Êvropoû" ta „Russkim mirom”, Kiïv 2009, s. 7-26. Z kolei potencjał heurystyczny różnych ujęć dziejów Ukrainy: środkowoeuropejskiego (Rzeczpospolita do 1795 r., monarchia habsburska), wschodnioeuropejskiego (Ruś, Slavia Orthodoxa), a nawet eurazjatyckiego (Mongołowie, Tatarzy, imperium rosyjskie XVIII-XIX w., ZSRR) zanalizował Jarosław Hrycak (Âroslav Gricak). Jego zdaniem raczej nie należy mówić o ich wzajemnym wykluczaniu się, lecz o uzupełnianiu - idem, On Sails and Gales, and Ships Sailing in Various Directions: Post-Soviet Ukraine, „Ab Imperio” 2004, 1, s. 230-251. 
czenie inicjatyw na rzecz tolerancji religijnej oraz przekroczenia rozłamu chrześcijaństwa na wschodnie i zachodnie oraz recepcji na ziemiach prawosławnych wzorów i osiągnięć cywilizacji łacińskiej (unia brzeska, unia w Siedmiogrodzie) $)^{25}$.

Efekt tego przedsięwzięcia prowadzi do esencjalizacji Europy Środkowo-Wschodniej jako regionu o wspólnej trajektorii losu historycznego na przestrzeni całego tysiąclecia. Autorzy wykazują podobieństwa przemian cywilizacyjnych w Polsce, Czechach i na Węgrzech od X do XVI w., nie potrafią jednak przekonująco „włączyć” do regionu ziem ruskich, gdzie podobne kierunki rozwoju zaznaczyły się dopiero od XIV stulecia. Nie mogą także wykazać - a koncepcja regionu powinna to zakładać - iż związki polityczne między należącymi do niego krajami były bardziej intensywne niż między nimi a ich sąsiadami, a także, iż istniała, choćby tylko między samymi monarchami, jakakolwiek wspólna tożsamość. Nie można zaprzeczyć temu, iż Polskę, Czechy i Węgry w średniowieczu łączyło wiele cech wspólnych, wynikających z recepcji cywilizacji łacińskiej, ale czy fakt ich pozostawania w tym samym stosunku zależności od Zachodu jest wystarczający, aby mówić o Europie Środkowo-Wschodniej? A nawet więcej aby uznać, iż wspólna trajektoria ich rozwoju została do tego momentu wskutek tej zależności zdeterminowana, a także, że ich oddziaływanie na wschodzie (szczególnie Polski!) wpłynęło nieodwracalnie na wejście na tę samą trajektorię krajów bardziej na wschód położonych?

Po pierwsze, konstrukcja syntezy „lubelskiej”,,pęka” na granicy północnych Karpat. W epoce od X do początku XIV w. udaje się wprawdzie wykazać pewne związki polityczne między władcami Polski i Węgier (z pewnością jednak, wyjąwszy książąt krakowskich w XIII w., mniej intensywne niż związki Piastów z księstwami i marchiami wschodnimi Rzeszy, które według autorów do regionu nie należały), jednak gospodarki tych państw funkcjonowały w innych sieciach powiązań, gdyż ówczesny handel europejski toczył się głównie na szlakach położonych w układzie równoleżnikowym. Region Europy Środkowo-Wschodniej - tu trzeba zgodzić się z J. Kłoczowskim - w wymiarze politycznym nabrał natomiast nieco wyraźniejszych konturów w epoce XIV-XVI w. Od obrania przez Władysława Łokietka strategii na porozumienie z Andegawenami po unię Rzeczypospolitej z Siedmiogrodem przez osobę Stefana Batorego trwał okres intensywniejszych kontaktów politycznych, w którym współpraca przeważała nad konfliktami. Dodając do tego rozwój handlu - w układzie równoleżnikowym oraz

${ }^{25}$ Zob. J. Kłoczowski, Tolerancja w Rzeczypospolitej polsko-litewskiej: konstytucja z 1573 roku o zachowaniu pokoju religijnego oraz Unia brzeska, w: Historia Europy Środkowo-Wschodniej, t. 2, s. 88-118. 
transkarpackiego - epoka rządów w państwach regionu ostatnich Piastów oraz Andegawenów i Jagiellonów wydaje się okresem, w którym „lubelski" koncept Europy Środkowo-Wschodniej broni się względnie najlepiej przed zarzutami.

Inaczej niż w periodyzacji przyjętej w tym dziele druga połowa XVI w. i wiek XVII były jużjednak okresem postępującego rozchodzenia się orientacji politycznych i gospodarczych tych trzech państw ${ }^{26}, \mathrm{z}$ których Czechy i Węgry były rządzone przez dynastię cesarską. $Z$ jednej strony protestanci czescy i węgierscy stale należeli do przeciwnego niż Rzeczpospolita układu sił w Europie, z drugiej nie można jednak mówić o pełnej wspólnocie interesów (może z wyjątkiem dwu ostatnich dekad rządów Zygmunta III) między dwoma głównymi siłami katolickimi w regionie - starszą linią Wazów oraz Habsburgami. Nie przypadkiem zapewne w omawianej syntezie dla XVIII i XIX w. nie udało się przygotować jednolitego opracowania. Czechy i Węgry wchodziły w skład całkiem odmiennego niż Polska - wyjąwszy Galicję od 1772 r. - organizmu politycznego i gospodarczego. Przejęcie przez Prusy Śląska i wymarcie tamtejszych Piastów ostatecznie rozdzieliło też Czechy i Polskę, zatem od połowy XVIII w. prowincja ta przestała odgrywać rolę - co miało miejsce w średniowieczu - „mostu” łączącego oba kraje.

Po drugie, brak tysiącletniej „spoistości” regionalnej Europy Środkowo-Wschodniej uwidacznia się na granicy między łacińskim a prawosławnym kręgiem kulturowym. Wejście południowej i środkowej części dawnej Rusi Kijowskiej w skład Wielkiego Księstwa Litewskiego, a następnie Rzeczypospolitej Obojga Narodów zapoczątkowało procesy transmisji kultury zachodniej na wschód oraz osmozy dwu kultur (w pewnej mierze nawet trzech, trzeba bowiem uwzględnić także wpływ tatarski i muzułmański), co uwidoczniło się w stylu życia, tożsamości i przekonaniach politycznych elit - szlachty, części mieszczaństwa i starszyzny kozackiej. Jednak w dłuższej perspektywie zmiany przez nie wywołane okazały się już to ograniczone (na bardziej geograficznie zachodnich obszarach Rusi), już to nietrwałe (na obszarach naddnieprzańskich).W każdym razie w stuleciach od XIV do XVIII nie można mówić o na tyle głębokich przemianach struktury społecznej oraz kultury i mentalności ziem dawnej Rusi, zwłaszcza odnośnie do niższych warstw ludności, aby trajektoria jej dziejów została „ostatecznie” skierowana ku Zachodowi. Wynikało to przede wszystkim z charakteru państwa polsko-litewskiego w epoce nowożytnej, które na swych ziemiach wschodnich oddziaływało bardziej jako wzór obywatelskiej wspólnoty politycznej, zarządzanej jednak z odległego centrum i bezpośrednio doświadczanej rzadko - na sejmikach czy czasie kampanii wojennych, nie istniało

${ }^{26}$ Historia Europy Środkowo-Wschodniej, t. 1, s. 169-190. 
natomiast w świadomości masowej jako źródło stałych praktyk administracyjnych. W tej części państwa Rzeczpospolita była utożsamiana ze społecznym panowaniem szlachty i uprzywilejowaniem Kościoła katolickiego, które przez długie dwa stulecia - od powstania Semena Nalewajki (Semen [Severin] Nalivajko) (1596) po ruch hajdamacki Iwana Gonty (İvan G̀onta) i Maksyma Żeleźniaka (Maksim Zalìznâk) (1768) - kilkakrotnie przez miejscową ludność zostały jednoznacznie odrzucone. Wynikało to także z faktu powstrzymywania aż do 1905 r. procesu modernizacji społeczeństwa i państwa przez władze Rosji carskiej. W XIX w. paradoksalnie przyczyniło się to do wydłużenia okresu wpływu społecznego i kulturowego polskiej i spolonizowanej szlachty na Kresach wschodnich dawnej Rzeczypospolitej.

W sytuacji wyjątkowej na tle dziejów całości ziem ruskich znalazła się jedynie Ruś Czerwona (Halicka i południowa część Włodzimierskiej). I to z dwu względów. Po pierwsze dlatego, że transmisja kultury zachodniej przez Polskę i Węgry trwała tu najdłużej, po drugie - co istotniejsze - że proces ten nie został przerwany przed nadejściem nowoczesności, lecz pogłębiony i przyśpieszony wskutek wejścia jej w granice państwa habsburskiego w 1772 r. Dla tutejszej inteligencji ruskiej w XIX w. cywilizacja Zachodu, wraz z pochodzącą od niego ideą narodu, stała się podstawowym punktem odniesienia, nie nastąpiło jednak „przecięcie” przez nią więzi z prawosławną kulturą i dziedzictwem historycznym Rusi południowej. Świadczyło o tym i to, że proces latynizacji cerkwi unickiej pod rządami austriackimi został przez należące do niej duchowieństwo powstrzymany, i to, że porzucono ówczesne projekty wprowadzenia w piśmiennictwie alfabetu łacińskiego. Najważniejszym przejawem tego, iż tożsamość ruskiej inteligencji Galicji Wschodniej była w XIX i XX w. tyle środkowoeuropejska, ile wschodnioeuropejska, był charakter ukształtowanej przez nią ideologii narodowej. Stanęła ona wobec wyboru, w jakim projekcie narodotwórczym uczestniczyć - ruskim (z udziałem Wielko-, Mało- i Białorusinów, czyli całości ludności słowiańskiej i prawosławnej Rosji), ruteńskim (przez zjednoczenie ludności ruskiej samych Austro-Węgier) czy ukraińskim (na podstawie historycznej odrębności ziem południowej Rusi znajdujących się w granicach obu imperiów). W latach osiemdziesiątych-dziewięćdziesiątych XIX w. większość wybrała ostatecznie trzeci z tych projektów i obecnie czwarte już pokolenie wschodniogalicyjskich elit - mimo współczesnych problemów politycznych wynikających z tożsamościowej dwoistości narodu ukraińskiego - pozostaje mu wierne. Warto wszakże pamiętać, że przynajmniej do końca II wojny światowej narodowy projekt ukraiński, także w przekonaniach inteligencji zachodnioukraińskiej (a nie tylko obywateli USRR), sięgał 
bardzo daleko na wschód - przez terytorium Kubania „ocierał” się wręcz o północne stoki Kaukazu.

W syntezie „lubelskiej” pewna niespójność między poszczególnymi autorami ujawnia się także w podejściu do kwestii narodowej. H. Samsonowiczowi i J. Kłoczowskiemu bliskie jest podejście umiarkowanie perennialistyczne. Pierwszy z nich już w XII w. przypisuje w Polsce nie tylko rycerstwu, ale także i kmieciom poczucie „odrębności językowej i obyczajowej” oraz postawy „patriotyczne” ${ }^{27}$. Drugi z kolei u reprezentantów stanów uczestniczących w podejmowaniu decyzji państwowych w Polsce, Czechach i na Węgrzech (rycerstwa - szlachty, części mieszczaństwa) w XIV-XVI w. spostrzega świadomość narodową o charakterze historycznym i kulturowym, nieróżniącą się w istocie od nowoczesnego przeżywania uczestnictwa $\mathrm{w}$ narodzi ${ }^{28}$. W tym kontekście jego stanowisko pozostaje zbliżone - choć nieco ostrożniejsze - do tych historyków ukraińskich, którzy, jak Natalia Jakowenko (Natalâ Âkovenko), argumentują za kształtowaniem się osobnej świadomości narodowej wśród Kozaków i szlachty Wołynia, Podola i Ukrainy w XVII w. ${ }^{29}$ Wskazuje na to posługiwanie się przez niego terminologią (raczej „Ukraina” i „ukraiński” niż „Ruś” („Mała Ruś”) i „ruski”), a także żal z powodu zaniechania realizacji przez Rzeczpospolitą projektu unii hadziackiej (1658) jako rozwiązania, które mogło przyczynić się do ostatecznego uformowania narodu ukraińskiego i powstrzymania na Ukrainie panowania rosyjskiego ${ }^{30}$.

Inne stanowisko względem kwestii narodowej zajmuje natomiast D. Beauvois. Nie jest to z pewnością reprezentant modernizmu (raczej etnosymbolizmu) ${ }^{31}$.Jednak pokazuje on powstanie pięciu narodów (Polacy, Litwini, Białorusini, Ukraińcy i Żydzi) na obszarze dawnej Rzeczypospolitej w epoce nowoczesności jako wynik zbiegów okoliczności, a nie nieunikniony rezultat toczących się od średniowiecza procesów historycznych. Upadek Rzeczypospolitej, zanim reformy podjęte w drugiej połowie XVIII w. zdążyły ją zmodernizować, rozpad szlacheckiego „narodu politycznego", proces reintegracji wyznaniowej ludności na ziemiach dawnej Rusi w granicach państwa rosyjskiego w XIX w. (kasata unii), prowadzona przez Rosję i Austrię polityka preferowania jednych narodowości wzglę-

${ }^{27}$ Ibidem, s. 59.

${ }^{28}$ Ibidem, s. 166-169, 239-241.

${ }^{29}$ N. Jakowenko, Historia Ukrainy. Od czasów najdawniejszych do końca XVIII w., Lublin 2000, s. 283-303.

${ }^{30}$ Historia Europy Środkowo-Wschodniej, t. 1, s. 186-189, t. 2, s. 86-87.

${ }^{31}$ Jak przedstawiciele tych dwu paradygmatów, a także wcześniej wspomnianego perennializmu, we współczesnych studiach nad narodem i nacjonalizmem wyjaśniają powstanie narodu, zob. A. D. Smith, Nationalism and Modernism. A critical survey of recent theories of nations and nationalism, London-New York, 1999. 
dem drugich, stosunki społeczne na dawnych Kresach antagonizujące dwór i wieś według kryterium podziału kulturowego, w końcu irredentystyczne dążenia Polaków, będące tyleż rywalem, co wzorem dla ruchów politycznych innych narodów w regionie, otworzyły drogę powstaniu pięciu nowych wspólnot etniczno-kulturowych ${ }^{32}$. Wprowadzenie do omawianej syntezy rozdziałów napisanych przez D. Beauvois niewątpliwie wzbogaciło obraz historii ziem regionu o świadomość tego, że procesy narodotwórcze mogły toczyć się wielowariantowo. Idąc za tym rozumowaniem, należałoby się zgodzić z Aleksiejem Millerem (Aleksej Miller) co do przekonania, iż w XIX w. w imperium carskim, obok wariantu zrealizowanego - powstania trzech narodów wschodnich Słowian, szanse realizacji miał także wariant planowany w Petersburgu - zjednoczenia całej ludności prawosławnej w ramach trzyczęściowego narodu rosyjskiego ${ }^{33}$.

Zastrzeżenia te prowadzą do postawienia poważnego znaku zapytania nad możliwością realizacji spójnej koncepcji tysiącletniej historii Europy Środkowo-Wschodniej nawet w „lubelskiej”, ograniczonej terytorialnie, wersji regionu (w żadnym razie nie dotyczą natomiast kompetencji autorów jako znawców poszczególnych epok). W istocie, jak sądzę, w historiografii jest sens używać terminologii regionalnej, bez niej zresztą „umarłaby" komparatystyka, wszakże pod dwoma jednoczesnymi warunkami. Po pierwsze, w odniesieniu do każdej epoki trzeba zaznaczyć, jakie są granice występowania wspólnych zjawisk i jak te granice biegły w epoce poprzedniej oraz zmieniły się w epoce następnej. Po drugie, należy wystrzegać się narracji o wydźwięku tożsamościowym, która w przypadku Europy Środkowej (Środkowo-Wschodniej) powstaje głównie wskutek zaznaczania stopnia recepcji elementów kultury zachodniej w porównaniu z obszarami znajdującymi się dalej w kierunku wschodnim i/lub południowym (prowadzi to do swego rodzaju „komparatystyki cywilizacyjnej”, w której przekonanie o własnej niepełnowartościowości wobec

${ }^{32}$ Ibidem, t. 1, s. 267-316, t. 2, s. 45-49.

${ }^{33}$ Perspektywa ta byłaby naturalnie bardziej prawdopodobna, gdyby w końcu XIX w. inteligencja wschodniogalicyjska ostatecznie nie złączyła swych wysiłków narodotwórczych z ukrainofilami naddnieprzańskimi. Zob. A. Miller, „Ukrainskij vopros” $v$ politike vlastej i russkom obŝestvennom mnenii (vtoraâ polovina XIX veka), Sankt-Peterburg 2000. Zob. także krytykę polskich debat na temat Europy Środkowo-Wschodniej, w tym koncepcji Kłoczowskiego, w polemikach Millera z Andrzejem Nowakiem (A. Miller, Mental'nye karty istorika i svâzannye s nimi opasnosti, w: Central'naâ Evropa kak istoričeskij region, red. idem, Moskva 1996, s. 4-25; idem, Tema Central'noj Evropy: istoriâ, sovremennye diskursy i mesto $v$ nih Rossii, „Novoe literaturnoe obozrenie” 2001, 52 $\langle$ http://magazines.russ.ru/nlo/2001/52/〉 (dostęp: 31 I 2013); idem, Europa Wschodnia - potrzeba nowej wizji, „Arcana” 2002, 2 (44), s. 76-82). 
centrum kompensuje się poczuciem satysfakcji z tego, iż istnieją terytoria jeszcze bardziej peryferyjnie wobec niego położone) ${ }^{34}$.

W tej sytuacji całościowe (tysiącletnie) syntezy historii Europy Środkowej (Środkowo-Wschodniej) wydają mi się wątpliwe. Można (i z pewnością warto!) napisać historię porównawczą Polski, Czech, Węgier, Chorwacji, Słowenii i (a może także Słowian Połabskich?) w epoce od IX-X do XVI w., liczba wspólnych cech i podobnych doświadczeń daje bowiem podstawy do tego, aby zaproponować ujęcie regionalne. L. Kontler - m.in. za Jenő Szücsem ${ }^{35}$ - zalicza do nich: chrystianizację w obrządku łacińskim, podział władzy między monarchę i uprzywilejowane stany, stosunki feudalne ujęte w zasady prawa, samorządne miasta i rozdział pracy między nimi a ich wiejskim otoczeniem, recepcję kultury rycerskiej, w końcu wpływ renesansowego humanizmu i reformacji. Dla niego są to „fundamenty" Europy Środkowej, zauważmy jednak, iż żaden z nich nie pojawia się później niż na początku XVI stulecia ${ }^{36}$. W tym wieku trajektorie dziejów owych krajów „rozeszły” się, by zacząć „wracać” ku sobie od połowy XIX stulecia, nastąpiło to jednak w daleko szerszym gronie niż w średniowieczu. Czynnikiem łączącym były dążenia ruchów narodów bezpaństwowych przeciwko postanowieniom kongresu wiedeńskiego (1815) i berlińskiego (1878), zatem granice regionu „przesunęły” się wyraźnie w każdą stronę z wyjątkiem kierunku zachodniego, obejmując całą przestrzeń między Bałtykiem, Adriatykiem, Morzem Egejskim i Morzem Czarnym (Czechy i Słowenia w okresie XVI-XVII w. pozostały w związku ze sobą poprzez podległość Habsburgom, ale sąsiednia Chorwacja i Węgry w całości zostały złączone z nimi dopiero wskutek zwycięstwa Austrii nad Turcją i pokoju karłowickiego w 1699 r.).

W odniesieniu do średniowiecza można mówić o dwu regionach - recepcji wzorów łacińskich i bizantyjskich. Pierwszy obejmował wyżej zarysowany region krajów, które przyjęły obrządek łaciński i bezpośrednio sąsiadowały od wschodu z centrami cywilizacyjnymi - Włochami (siedzibą papiestwa) i/lub cesarstwem. Drugi dotyczył krajów, które przyjęły obrządek wschodni - od Rusi po Serbię i wybrzeże Adriatyku. Od początku był on bardziej zróżnicowany wewnętrznie. Jak zauważa inny zwolennik kon-

${ }^{34} \mathrm{O}$ odbiorze współczesnych debat na temat Europy Środkowej w społeczeństwie do niej najczęściej niezaliczanym - Ukrainie zob. O. Hnatiuk, Pożegnanie z imperium. Ukraińskie dyskusje o tożsamości, Lublin 2003, s. 173-230.

${ }^{35}$ J. Szücs, Trzy Europy, Lublin 1995 (tł. z wyd. fr. 1985, oryg. węg. 1981).

${ }^{36}$ Jednocześnie Kontler nie traktuje ich jako historycznego „stanu rzeczy”, lecz jako „typy idealne” i „narzędzie heurystyczne”. Ich zestawienie we wstępie służy mu, inaczej niż w syntezie autorów polskich, nie do nadania unikalności i ciągłości dziejom kilku krajów, lecz do umieszczenia w perspektywie porównawczej historii jednego kraju - Węgier - L. Kontler, op. cit., s. 19. 
cepcji Europy Środkowej Antoni Podraza, państwa bałkańskie powstały w VII-IX w. na obszarze, który w starożytności doświadczył panowania rzymskiego, a we wczesnym średniowieczu został schrystianizowany przez lub pod bezpośrednim wpływem cesarstwa wschodniego ${ }^{37}$. Państwo na osi Dniepru ze stolicą w Kijowie powstało w inny sposób niż państwa na półwyspie Bałkańskim, później niż tamte przyjęło chrzest, w odróżnieniu od nich nie znalazło się w strefie zależności politycznej od Konstantynopola. Mimo że w XIII-XV w. przeszło przez okres zależności od Tatarów, to przeciwnie niż Bułgaria, Serbia, księstwa naddunajskie i sama Grecja zachowało odrębność i odrodziło się w XV w. jako samodzielny ośrodek polityczny i kulturowy z centrum w Moskwie. Odrodziło, a nawet - w związku z podbojem Konstantynopola przez Turków w 1453 r. - zgłosiło pretensje do dziedzictwa imperium rzymskiego i bizantyjskiego. Jednak objęło tylko obszary Rusi wschodniej i północnej, a następnie, do połowy XVII w., rozwijało terytorialnie jedynie w kierunku wschodnim, skutkiem czego daleko wykroczyło poza jakiekolwiek pojęcie „Europy”. Państwa bałkańskie zostały natomiast w XIV i XV w. trwale podbite przez islamską Turcję. Zachowały względem Stambułu i Anatolii odrębność kulturową (przy silnym wpływie duchowieństwa greckiego), jednak jako samodzielne podmioty „powróciły” do polityki w Europie „dopiero” wraz z początkiem nowoczesności w XIX w.

W średniowieczu być może zatem lepiej byłoby mówić o trzech regionach. Jeśli ktoś chce nazywać je - odpowiednio do kolejności, w której zostały przedstawione - Europą „Środkową", „Południowo-Wschodnią” i „Wschodnią”, potrafi pisać o nich w sposób pozbawiony odniesień tożsamościowych, a także ze świadomością tego, jak bardzo zmieniły się one w następnej epoce - w późnym średniowieczu lub wczesnej nowożytności pierwszy z nich „rozpadł” się, drugi stracił samodzielność polityczną i wszedł w granice imperium położonego na trzech kontynentach, a centrum trzeciego przesunęło się na dotychczasową granicę świata schrystianizowanego (zatem według ówczesnych pojęć europejskiego) niech tak postępuje. Być może jednak lepiej dla bezstronności badawczej i ciekawości intelektualnej byłoby opracowywać komparatystyczne historie dwu lub większej liczby krajów należących do jednego regionu lub - co znacznie bardziej interesujące - reprezentujących różne regiony. Wobec tej argumentacji można przedstawić zarzut, iż kategoria kraju (np. „Polska” czy „Rumunia”) jest w istocie nie mniej skonstruowana

${ }^{37}$ A jednocześnie przeciwnik koncepcji Europy Środkowo-Wschodniej, zob. A. Podraza, Europa Środkowa jako region historyczny, w: idem, Europa. Galicja. Regiony. Pisma historyczne, oprac. G. Nieć, Kraków 2006, s. 27-38. 
(jest pochodną pojęcia narodu rodem z XIX w.) niż kategoria regionu. Trudno byłoby się z tym nie zgodzić ${ }^{38}$. Są jednak dwie racje na rzecz tego rozumowania. Po pierwsze, nie trzeba porównywać Polski z Rumunią i Rusią w późnym średniowieczu, można zająć się natomiast np. ziemią sandomierską, Oltenią i księstwem czernichowskim w tym okresie. Po drugie, opracowywanie całościowych syntez historii krajów, których współczesne granice i tożsamość mieszkańców ukształtowały się dopiero pod wpływem wydarzeń ostatniego półtorawiecza, ma oczywiście charakter teleologiczny, jednak ze względu na dydaktyczno-formacyjną funkcję historiografii w świecie składającym się z państw narodowych jest nieuniknione. Można jedynie dodać, iż zadania tego mogą się podejmować nieliczni (swoją drogą nigdy chętnych do tego nie brakuje) spośród ogółu reprezentantów cechu historyków.

Wobec nowożytności także istnieją przesłanki, aby mówić o trzech regionach: południowo-wschodnioeuropejskim (pod panowaniem tureckim od XIV-XV do XIX w.), środkowoeuropejskim (pod panowaniem habsburskim od początku XVI do początku XX w.) i - „nowym” - środkowo-wschodnioeuropejskim (w granicach państwa polsko-litewskiego od końca XIV do końca XVIII w.). Powstaje jednak pytanie, co taki podział wniósłby do naszego rozumienia historii Europy między późnym średniowieczem a epoką nowoczesną. Czy wprowadzenie takiej terminologii jakkolwiek wzbogaciłoby nasze możliwości interpretacyjne w stosunku do powszechnie używanej nomenklatury państwowej? Moim zdaniem nic za tym nie przemawia. Nie pojawiły się wówczas żadne kolejne cechy, które „wzmocniłyby” fundament tego, co L. Kontler uznał za charakter Europy Środkowej. Byłoby to tym bardziej wątpliwe, że drugie i trzecie z tych pojęć współcześnie łatwo sprowadzić można do idei oddziaływania na wschodzie dwu kultur narodowych - niemieckiej (co w projektach Europy Środkowej F. Lista i F. Naumanna właśnie nastąpiło) ${ }^{39}$ i polskiej (czego wyrazem były echa ruchu prometejskiego, które dają o sobie znać w projektach polityki wschodniej Polski od lat osiemdziesiątych XX w. do dziś) $)^{40}$. W obu przypadkach szło o realizację wizji politycznej na jednoznacznie określonej podstawie tożsamościowej. Nie dostrzegam heury-

38 O tym, że wyobrażenie regionu podlega w istocie tym samym mechanizmom co konstruowanie pojęcia narodu, nie jest to zatem w humanistyce droga, która prowadzi do wyjścia poza ograniczenia narracji narodowej, zob. I. Neumann, Uses of the Other. „The East” in European Identity Formation, Minneapolis 1999.

${ }^{39}$ Zob. B. Stråth, Mitteleuropa. From List to Naumann, „European Journey of Social Theory" 11, 2008, 2, s. 171-183. O Liscie także R. Szporluk, Communism and Nationalism. Karl Marx versus Friedrich List, New York-Oxford 1988.

${ }^{40}$ Zob. Ruch prometejski i walka przebudowę Europy Wschodniej 1918-1940. Studia i szkice, red. M. Kornat, Warszawa 2012. 
stycznych korzyści dla historyków z konceptu jakiegokolwiek regionu w Europie od XVI do XIX w., którego granice pokrywają się z zakresem rządów jednego ośrodka władzy, nawet tak potężnego jak ówczesny Wiedeń czy Stambuł. Mogłoby to prowadzić do legitymizowania przez naukę publicystyki służącej dowartościowywaniu kultury jednego narodu kosztem jego wschodnich sąsiadów, a w płaszczyźnie strategii politycznych do uzasadniania domniemanymi przewagami z przeszłości pretensji jednego państwa do przywództwa regionalnego.

Europa Środkowa (Środkowo-Wschodnia) w polityce - niezrealizowany projekt wspólnotowy

W moim przekonaniu pojęcia „Europy Środkowej” (,Środkowo-Wschodniej") nie tyle można, ile wręcz warto natomiast używać w odniesieniu do czasów, które zaczęły się wtedy, gdy ta część kontynentu została wyobrażona. Wyobrażenie to pojawiło się jednak później niż dwa inne pojęcia, które legły u podstaw nowoczesności i do dziś określają ramy postrzegania historii Europy. Mam tu na myśli po pierwsze cywilizacyjny koncept Europy Wschodniej, po drugie nowoczesne pojęcie narodu. Oba sensu zbliżonego do współczesnego zaczęły nabierać w epoce oświecenia. Pierwszy wywodził się z relacji z podróży, korespondencji z monarchami oraz prób skartografowania, jakie podjęli w stosunku do ziem położonych na wschód od Łaby, Alp i Adriatyku intelektualiści przybywający z zachodniej części kontynentu. Pojęcie to przez następne półtora stulecia było nieodłącznie związane z przekonaniem utożsamiającym cywilizację z dorobkiem krajów położonych nad Atlantykiem oraz na półwyspach Morza Śródziemnego. Do takiej Europy Wschodniej w XVIII w. zaliczono tak łacińską Polskę, jak prawosławną Rosję oraz w dużej mierze już islamską Bośnię i Albanię ${ }^{41}$. Przeciwstawienie się tej wartościującej typologii stanowiło wspólny motyw tutejszych intelektualistów, którzy przez następne dwa stulecia własne narody wyobrażali sobie jako część Europy Środkowej (Środkowo-Wschodniej).

Nowoczesne pojęcie narodu jako wspólnoty historycznej, masowej i terytorialnej oraz $\mathrm{w}$ tym sensie politycznej, że stale realizującej jakiś projekt przyszłości, też ukształtowało się w odniesieniu do oświeceniowej idei postępu. To właśnie wtedy intelektualiści z tej „drugiej” Europy zaczęli sobie uświadamiać, że kraje, które reprezentują, dla dorównania standardom tej „pierwszej”, i tym samym „dołączenia” do niej, muszą

${ }^{41}$ Zob. L. Wolff, Inventing Eastern Europe. The Map of Civilization on the Mind of the Enlightenment, Stanford 1994. 
najpierw stać się narodami. W późnym XVIII w. drogę temu kierunkowi myślenia w Europie na wschód od Łaby i Adriatyku torowały projekty zmodernizowania Rzeczypospolitej pod panowaniem Stanisława Augusta Poniatowskiego.

Między początkiem ruchu sprzeciwu kolonistów amerykańskich wobec Korony Brytyjskiej oraz publikacją Umowy społecznej Jeana-Jacques'a Rousseau a Wiosną Ludów w Europie trwał okres, w którym pojęcie narodu nabierało znaczenia rewolucyjnego. Jednak wtedy prawo do posiadania własnej jednostki politycznej przypisywano jedynie wspólnotom o dużym zasięgu terytorialnym, legitymizującym się związkiem z państwem o długiej i nieodległej przeszłości, posiadającym własną elitę kulturalną i administracyjną, w końcu mającym „udowodnioną" historycznie zdolność do podboju ${ }^{42}$. Przynajmniej do $1848 \mathrm{r}$. wielkie projekty rewolucyjnej przebudowy Europy - od Giuseppe Mazziniego po twórców Manifestu Komunistycznego - opierały się na takich właśnie narodach „historycznych”, a zasada etniczna nie była traktowana jako podstawa ładu politycznego. Wyobrażenie Europy Środkowej pojawiło się po raz pierwszy u F. Lista w latach czterdziestych XIX w., nie była to jednak jeszcze wizja zjednoczenia regionu na zasadach równości zamieszkujących go narodów, lecz raczej liberalno-ekonomiczna odmiana ,wielkoniemieckiego" projektu narodowego ${ }^{43}$. Między połową stulecia - przełomem była tu Wiosna Ludów w krajach monarchii habsburskiej - a rokiem 1871, gdy zakończył się proces formowania państwowości trzech „starych" narodów: Włoch, Niemiec i Węgier, rosła siła ruchów, które żądały uznania języka i kultury etnicznej za podstawę ładu politycznego. Z kolei między kongresem paryskim (1856) a berlińskim (1878) zasadę tę faktycznie zaczęły uznawać mocarstwa, choć ich zgoda na razie dotyczyła jedynie nieobjętej gwarancjami międzynarodowymi strefy władania otomańskiego (Serbia, Rumunia, Bułgaria). W końcu stulecia tendencja ta była już bardzo wyraźna nie tylko na Bałkanach i w obu częściach państwa habsburskiego, ale także w całym zachodnim, od Morza Białego do Morza Czarnego, i południowym, od Dunaju po Kaukaz, pasie ziem cesarstwa rosyjskiego ${ }^{44}$.Jednocześnie po zjednoczeniu Włoch i Niemiec i powstaniu państw o ustroju konstytucyjnym w Europie na zachód od Łaby i Adriatyku osłabła dynamika kwestii narodowej jako czynnika zmian terytorialno-politycznych.

\footnotetext{
${ }^{42}$ E. Hobsbawm, Narody i nacjonalizm po 1780 roku. Program, mit, rzeczywistość, Warszawa 2010 (oryg. ang. 1990), s. 45-46.

${ }^{43}$ Zob. B. Stråth, op. cit., s. 171-183.

${ }^{44}$ Chodzi o model nacjonalizmu, który Ernest Gellner, niezbyt precyzyjnie, ujął jako „nacjonalizm «habsburski» ze szpicami na wschód i południe”, E. Gellner, Narody i nacjonalizm, Warszawa 2009 (oryg. ang. 1983), s. 191.
} 
Wobec tych przemian kontury środkowej (środkowo-wschodniej) części Europy zaczęły być wyraźniejsze niż kiedykolwiek przedtem. Sądzę, iż od połowy XIX w. można mówić o regionie rozciągającym się między Bałtykiem, Adriatykiem, Morzem Egejskim a Morzem Czarnym (którą z tych dwu nazw dla niego przyjmiemy, jest kwestią drugorzędną) nie tylko ze względu na zarysowane wyżej różnice z Europą Zachodnią, ale także dlatego, że nadchodząca nowoczesność przyczyniała się coraz bardziej do zmniejszania różnic występujących dotychczas między wchodzącymi w jego skład krajami łacińskimi i prawosławnymi ${ }^{45}$. O specyfice regionu decydowały, jak sądzę, dwie kwestie. Po pierwsze, był to obszar o unikalnym w skali światowej charakterze ideologii narodowych. Polegały one na powiązaniu heroicznych mitów historycznych i praw do terytoriów „etnicznych” z walką o emancypację społeczną i odnoszącymi się do Europy (Zachodu) projektami modernizacyjnymi. Realizacja tych projektów w okresie od wybuchu powstania serbskiego i greckiego na początku XIX w. do ostatecznego rozpadu Jugosławii na przełomie XX i XXI w. doprowadziła do powstania dwudziestu trzech państw narodowych - od Finlandii po Ukrainę i Grecję (licząc bez dawnych centrów imperialnych - Austrii, Turcji i Rosji). Weszły one w rolę organizacji mających za zadanie jednocześnie chronić przed światem mikrokosmos własnej kultury i zapewnić swym obywatelom udział w osiągnięciach cywilizacji światowej (czy gdziekolwiek indziej na świecie narody liczące 2-3 mln członków mają nie tylko własne literatury, ale także własne akademie nauk?). Po drugie, Europa Środkowa (Środkowo-Wschodnia) to także ta część kontynentu, w której na przestrzeni ostatniego półtorawiecza powstawały projekty polityczne odwołujące się do tożsamości regionalnej. Ich pomysłodawcy przeważnie nie kwestionowali pierwszeństwa identyfikacji narodowej, dążyli natomiast do uświadomienia tutejszym narodom przynależności do szerszej wspólnoty. Ich twórcy reprezentowali postulat czy to oparcia ładu politycznego na zasadzie samostanowienia, uzupełniony refleksją nad losem „małych narodów” i humanistyczną wizją urządzenia stosunków międzynarodowych (Tomáš Masaryk) ${ }^{46}$, czy to przekształcenia istniejących

${ }^{45}$ L. Kontler ma niewątpliwie rację, zwracając uwagę, iż dopiero kapitalistyczna przedsiębiorczość, oświecenie i nowoczesne ideologie polityczne w XIX w. były tymi wytworami Zachodu, które zostały szeroko zaadaptowane w Europie Południowo-Wschodniej i Wschodniej, co przyczyniło się do ich zbliżenia z krajami Europy Środkowej - L. Kontler, op. cit., s. 19.

${ }^{46}$ O Europie Środkowej nie jako o regionie o unikalnej historii czy obszarze wyróżnionym przez zagrożenie ekspansjonizmem Niemiec I Rosji, lecz reprezentatywnym dla różnych części świata „paśmie małych narodów”, które potrzebują niepodległości 
państw w federacje równych narodów (Aurel Popovici) ${ }^{47}$. Przeważnie projekty te dotyczyły tylko jakichś części całego obszaru między wspomnianymi czterema morzami, jednak fakt ich występowania właśnie w tej części Europy świadczy o jej swoistości historycznej w XIX i XX w.

Oznacza to, że wyobrażenie Europy Środkowej (Środkowo-Wschodniej) być może nie powstałoby, gdyby nie to, że na jej obszarze przeważają Słowianie. A w szczególności gdyby nie cecha ich myśli społeczno-politycznej, wyrażająca się w XIX i w pierwszej połowie XX w. w napięciu między ekskluzywizmem narodowym a ideą „wzajemności” (solidarności) między „spokrewnionymi” wspólnotami. Wyrastała ona po pierwsze $z$ daleko idącego podobieństwa między tutejszymi językami, po drugie z historii państwowej regionu, która, inaczej niż w zachodniej części kontynentu, pozostawiła historykom i ideologom narodowym szerokie możliwości konstruowania wzajemnie opozycyjnych (i z zasady teleologicznych) syntez dziejowych.

Jeśli przyjmiemy, iż koncept środkowo-(wschodnio-)europejskości polega na wizji organizacji międzynarodowej, która odwołuje się do równości narodów i współpracy między nimi, pierwszym jego reprezentantem był nie F. List, lecz Karel Havliček Borovský i František Palačký oraz uczestnicy kongresu słowiańskiego w Pradze. Styk niemiecko-czeski okazał się najbardziej płodny także i dla dalszego kształtowania się idei „środka Europy". O ile austroslawizm F. Palačkiego był wtedy alternatywą dla wizji rewolucji niemieckiej i węgierskiej, o tyle u schyłku I wojny światowej wizja Europy Środkowej T. Masaryka stanowiła odpowiedź na projekt Mitteleuropy F. Naumanna. Specyficznie środkowoeuropejski charakter miał wtedy także austromarksizm, którego twórcy odrzucili przekonanie Karola Marksa i Fryderyka Engelsa, iż państwo w dobie rewolucji przemysłowej musi prowadzić do unifikacji ludności, eliminując wewnętrzne różnice tożsamościowe. Innym wyrazem poszukiwania drogi do budowy państwa zdolnego do funkcjonowania w modernizującej się Europie była illiryjska (potem jugosłowiańska) idea zjednoczenia Słowian południowych, której w drugiej połowie XIX w. patronował biskup Josip Juraj Strossmayer. W ten kierunek myślenia wpisała się w także idea braterstwa Słowian podległych władzy cara głoszona przez Mykołę Kostomarowa (Mikola Kostomarov) (1846), a następnie projekty federalizacji państwa rosyjskiego (i radzieckiego)

\footnotetext{
i współpracy, w pismach Masaryka z lat 1914-1925 zob. J. Kilias, Naród a idea narodowa. Nacjonalizm T.G. Masaryka, Warszawa 1998, s. 195-212.

47 Zob. projekt podziału Austro-Węgier na jednostki narodowe i powołania Stanów Zjednoczonych Wielkiej Austrii - A. Popovici, Die Vereinigten Staaten von Groß-Österreich. Politische Studien zur Lösung der nationalen Fragen und staatsrechtlichen Krisen in Österreich-Ungarn, Leipzig 1906.
} 
w ukraińskiej myśli politycznej schyłku XIX i pierwszej tercji XX w. - od Mychajły Drahomanowa (Mihajlo Dragomanov) po Mychajłę Hruszewskiego (Mihajlo Gruševs'kij) ${ }^{48}$. Po kryzysie ładu wersalskiego w latach trzydziestych XX w. projekty federacyjne powróciły w czasie II wojny światowej i zimnej wojny, w środowiskach emigracji politycznych narodów Europy Środkowej (Środkowo-Wschodniej).

W takiej perspektywie historia regionu w ostatnim półtorawieczu jawi się jako przestrzeń projektów, które albo poniosły polityczne fiasko, albo w ogóle nie były realizowane. W XX w. silniejszy dystans wobec nich miały te narody, które albo w kontaktach $\mathrm{z}$ sąsiadami doświadczały własnej unikalności etnicznej, albo swe prawa do państwowości wprost wyprowadzały z tradycji którejś z potęg panujących tam do epoki nowożytnej. Pierwszą kategorię stanowili - otoczeni przez Słowian - Węgrzy, Rumuni i narody bałtyckie. Nie wydaje się dziełem przypadku, że w czasie II wojny światowej to przede wszystkim ich elity polityczne oparły strategię przetrwania/odbudowy państwa na współpracy z III Rzeszą i wzięły udział w wojnie na froncie wschodnim. Wiązały one nadzieje na znalezienie dla swych krajów miejsca w hitlerowskim wariancie projektu Mitteleuropy. Do nich dołączyli jednak także Słowacy i Chorwaci, narody słowiańskie należące wcześniej w całości do monarchii habsburskiej. Podobną próbę podjęli też w 1941 r. Ukraińcy we Lwowie, ten projekt nie spotkał się jednak z poparciem w Berlinie - m.in. dlatego, że daleko wykraczając poza ramy habsburskiej Galicji Wschodniej, dawał podstawy państwu, którego powstanie krzyżowałoby hitlerowskie plany kolonizacji wschodniej. Elity tych trzech narodów słowiańskich, aż do 1918 r. opowiadające się przeważnie za projektami federacyjnymi, rozczarowały się do ich realizacji w okresie międzywojennym. W latach trzydziestych wprowadziły do ideologii narodowych przekonanie o wyższości cywilizacyjnej Europy nad Wschodem, odwołując się głównie do katolicyzmu (na Słowacji) oraz do idei antemurale i teorii rasowych (w Chorwacji i w mniejszym stopniu na Ukrainie). Wszystkie te projekty spotkały się jednak w czasie wojny z silnym oporem tamtejszych społeczeństw, co znalazło wyraz w ruchu partyzanckim na terenie Niezależnego Państwa Chorwackiego i okupowanej Ukrainy oraz w powstaniu zbrojnym Słowaków przeciw państwu Jozefa Tisy w 1944 r. Wszystkie te ruchy stanowiły wyraz poparcia dla rozwiązań federacyjnych. Najdalej w tym kierunku szedł projekt zjednoczenia

${ }^{48} \mathrm{Na}$ miejscu będzie tu także przypomnienie myśli politycznej i akcji dyplomatycznej ks. Adama Jerzego Czartoryskiego oraz kierowanego przez niego Hôtel Lambert w Paryżu. Zob. M. Kukiel, Czartoryski a jedność Europy 1770-1861, Lublin 2008; J. Skowronek, Sprzymierzeńcy narodów bałkańskich, Warszawa 1983; P. Żurek, Hôtel Lambert i Chorwaci, Warszawa 2005. 
narodów bałkańskich Josipa Broz-Tity, zatrzymany jednak po wojnie przez Stalina, nieuznającego jakiejkolwiek konkurencji w ruchu komunistycznym.

Drugą natomiast kategorię narodów, które opierały się projektom ponadnarodowym, koncepcję środkowo-(wschodnio-)europejskości wiążąc silnie z projektami odbudowy swych państw w granicach „historycznych”, stanowili po raz kolejny Węgrzy, a także Polacy. W ich przypadku tradycje szlachty jako „narodu politycznego" nie sprzyjały w XIX i pierwszej połowie XX w. postrzeganiu innych narodów, powstałych w granicach ich państw „historycznych”, jako równych partnerów w rozwiązaniach federacyjnych ani skłonności do idei szerokiej współpracy politycznej krajów całej Europy Środkowej (Środkowo-Wschodniej), chyba że na warunkach przewodzenia całemu regionowi. Projekty federacyjne ogłoszone w $1918 \mathrm{r}$. przez przedstawicieli węgierskiej i polskiej lewicy (Oszkár Jászi, Józef Piłsudski) nie zyskały szerszej wiarygodności u adresatów. Choć w większym lub mniejszym stopniu przyznawały one prawo do podmiotowości politycznej narodom dawnych ziem Korony św. Stefana i Rzeczypospolitej Obojga Narodów, to jednak nie usuwały skutków panowania nad nimi węgierskich i polskich elit, nie wiązały zatem - a to należało do istoty nacjonalizmu w tej części świata - projektów przebudowy politycznej z hasłami przemian społecznych.

Na paradoks zakrawa to, że masowe uświadomienie przynależności do tego regionu nastąpiło dopiero wtedy, gdy po II wojnie światowej został on całkiem odcięty od Zachodu. Zjednoczenie państw Europy Środkowej (Środkowo-Wschodniej) w latach 1945-1989 nie oznaczało jednak, iż którykolwiek z wyżej wspomnianych projektów federacyjnych został zrealizowany. Nie tylko niekomuniści w tych państwach nie chcieli współpracy między narodami via Kominform czy centrale Rady Wzajemnej Pomocy Gospodarczej i Układu Warszawskiego w Moskwie, ale także sami komuniści, przynajmniej w pierwszej dekadzie po 1944 r., traktowali zjednoczenie akurat tych krajów jako rozwiązanie tymczasowe, dające podstawy do podjęcia ostatecznej walki o zwycięstwo rewolucji światowej. Nie tylko sposób realizacji współpracy międzynarodowej w regionie pod dyktando ZSRR okazał się chybiony. Wobec braku demokracji i wolności słowa w żadnym z trzech realizowanych projektów federacyjnych - radzieckim, jugosłowiańskim i czechosłowackim - nie udało się ukształtować kultury, z którą ludzie identyfikowaliby się przynajmniej w tym samym stopniu co z kulturą własnego narodu.

Tym, co najdobitniej potwierdza powstanie Europy Środkowej (Środkowo-Wschodniej) w świadomości jej mieszkańców w dobie jałtańskiego podziału kontynentu, był sposób, w który odeszła ona w przeszłość - 
Jesień Narodów w 1989 r. Kolejne kraje przełamywały wtedy monopol rządów komunistycznych i wychodziły ze strefy radzieckiej dominacji jak kostki domina, które w ruch wprawiła polska „Solidarność” w 1980 r. Nazwa tego ruchu społecznego stała się głośna od Gdańska po Sofię - to on wygenerował w $1981 \mathrm{r}$. dokument powracający do idei rewolucyjnej solidarności narodów regionu (Posłanie do ludzi pracy Europy Wschodniej) i to jego liderzy współtworzyli Solidarność Polsko-Czechosłowacką, ponadnarodowe porozumienie przeciwko rządom komunistycznym, nawiązujące do idei „niepolitycznej polityki” Václava Havla.

Przejście do demokracji i odzyskanie suwerenności przez państwa regionu w latach 1989-1991 otworzyło drogę badaniom nad formacją postkomunizmu. Próby porównywania w różnych krajach stopnia rozwoju opozycji politycznej i społeczeństwa obywatelskiego przed 1989 r., roli sił niezależnych oraz roli różnych frakcji nomenklatury w wydarzeniach, które doprowadziły do przełomu, miejsca zajętego przez przedstawicieli dawnej elity w nowym systemie politycznym, przebiegu procesów prywatyzacyjnych, ewolucji sceny partyjnej, w końcu postępów wprowadzania standardów państwa prawnego, przyczyniły się do odrodzenia refleksji nad podziałami wewnątrz grupy państw traktowanej dotąd jednolicie jako europejscy satelici ZSRR. W refleksji nad źródłami różnic stopnia efektywności reform i zaawansowania procesów transformacyjnych zaczęto zwracać uwagę na znaczenie dziedzictwa historycznego okresu sprzed rządów komunistycznych. Pojawiła się interpretacja, zgodnie z którą, jak napisali w 2010 r. redaktorzy całościowego opracowania zbiorowego przemian politycznych w regionie od $1989 \mathrm{r}$. Sabrina P. Ramet i F. Peter Wagner: „Wszystkie przypadki, które ogólnie są uznawane za należące do kategorii najlepszych praktyk [udanych procesów transformacyjnych - T.S.], zawierają się w tradycyjnej sferze Europy Środkowej [Polski, Czech, Słowacji i Węgier - T. S.] (wliczając w to Litwę, Łotwę i Estonię). Przypadki problematyczne znajdują się głównie w przestrzeni Europy Południowo-Wschodniej [państw pojugosłowiańskich, Rumunii, Bułgarii i Albanii - T.S.] i postsowieckiej przestrzeni nienależącej do UE [Białorusi, Ukrainy i Mołdowy - T. S.]" ${ }^{49}$.

Różnice między krajami położonymi w północnej i południowej części regionu zaczęto w pierwszej dekadzie XXI w. wyjaśniać w kategoriach path dependency theory, nie zawsze na szczęście interpretowanej (a już na pewno nie w przypadku cytowanych autorów) w sposób fatalistyczny. Pewne różnice między tymi dwoma grupami państw istnieją nie tylko w wyobraźni

${ }^{49}$ Polityka Europy Środkowej i Południowo-Wschodniej po 1989 roku, red. S. P. Ramet, Warszawa 2012, s. 42. 
badaczy. Widać je choćby we wskaźnikach percepcji korupcji Transparency International - jednak dystans między np. Polską a Bułgarią w tym względzie nie jest większy niż między tą pierwszą a np. Niemcami czy Danią. Nie wydaje się zatem, aby w dwie dekady po upadku komunizmu można było mówić o rozejściu się trajektorii rozwoju tych krajów i dzielić je na dwa regiony. Zresztą nawet i pozostali autorzy przywołanego opracowania nie byli w tej sprawie zgodni - część z nich nadal stosowała termin „Europa Środkowa” w odniesieniu do wszystkich, poza Rosją i Niemcami, państw postkomunistycznych w Europie.

Z perspektywy dwudziestolecia, które upłynęło od uformowania się mapy politycznej „nowej Europy”, widać jednak, iż idee współpracy regionalnej miały się gorzej niż w czasie poprzedniego półtorawiecza. Upadek komunizmu i rozpad ZSRR otworzyły drogę tryumfowi idei państwa narodowego. Potrzeba „nadrobienia” straconego czasu przez narody pozbawione suwerenności w poprzednim półwieczu wyraziła się w pragnieniu przeżywania emocji zbiorowych związanych z udziałem własnego państwa jako samodzielnego podmiotu w grze międzynarodowej.

W latach 1991-1993 upadły wspomniane trzy państwa federacyjne. Ani prezydentom Michaiłowi Gorbaczowowi (Mihail Gorbačëv) i Václavowi Havlovi, ani premierowi Ante Markoviciowi na przełomie lat osiemdziesiątych i dziewięćdziesiątych XX w. nie udało się stworzyć atrakcyjnej wizji demokratycznej modernizacji o charakterze ponadnarodowym. Choć wtedy mało kto obciążał wprost odpowiedzialnością za zbrodnie komunizmu narody stanowiące trzon państw federacyjnych (Rosjan, Serbów, Czechów), to jednak zapanowało przytłaczające przekonanie, że efekty modernizacji będą tym lepsze, im bardziej zunifikowane tożsamościowo będą państwa mające ją przeprowadzić. Niektóre z narodów, które nie posiadały własnych państw nie tylko w latach 1945-1991, ale także 19181939, okupiły realizację kursu na pełną niezależność kryzysem demokracji, która rozkwitła w czasach przełomu 1989-1991, i powrotem w latach dziewięćdziesiątych tendencji autorytarnych (znów, jak w 1941 r., Słowacja, Chorwacja i Ukraina, ale także Serbia i w pewnej mierze Rumunia).Zasadniczą rolę odegrała tu perspektywa wejścia do UE - organizacji, która wyewoluowała od założeń wspólnoty ponadnarodowej z lat czterdziestych w stronę forum dyplomatycznej gry państw narodowych. Rozpoczął się „wyścig do Europy”, rywalizacja o względy Zachodu, którego adresatem w największym stopniu była niemiecka i - odnośnie do członkostwa w NATO - amerykańska opinia publiczna. Wobec tej rywalizacji niewielką lub przejściową przydatność wykazały takie formy integracji regionalnej, jak Grupa Wyszehradzka (swoją drogą raczej projekt „wyprowadzenia” wąsko rozumianej Europy Środkowej z całego regionu niż próba repre- 
zentowania go jako całości) oraz Inicjatywa Środkowoeuropejska. Żadna z nich nie doprowadziła do powstania nowej siły w stosunkach międzynarodowych. W taki oto sposób wyzwanie europeizacji, rozumiane jako wizja „końca historii” tutejszych narodów, wraz z postępami procesu integracyjnego pochłonęło w ostatnich dwu dekadach wiele $\mathrm{z}$ tego, co było specyfiką tożsamościową omawianego regionu.

Dziś trudno nie cieszyć się z tego, że Europa Środkowo-Wschodnia stopniowo traci cechy regionu peryferyjnego, wydobywając się z zacofania cywilizacyjnego, w którym znalazła się wskutek rozejścia się dróg rozwoju gospodarczego dwu części kontynentu w XVI w. Nie sposób jednak nie dostrzec, iż jako region istnieje ona głównie w zainteresowaniach historyków. Po wydarzeniach pierwszej dekady XXI w. rozwiały się nadzieje na to, że „kolorowe rewolucje” w państwach b. ZSRR stanowią kontynuację procesu przemian zapoczątkowanego w Polsce w 1989 r. i uwieńczonego rozszerzeniem UE w 2004, 2007 i 2013 r. Koncept Europy Środkowo-Wschodniej, obejmującej także dążące do integracji z Zachodem narody b. ZSRR, „pękł” w latach 2008-2010 wraz z fiaskiem pomarańczowej rewolucji, załamaniem polityki negocjacji UE z reżimem Alaksandra Łukaszenki (Alâksandr Lukašènka) i użyciem siły przez Rosję wobec Gruzji dla obrony swojego statusu mocarstwowego. Niebagatelną rolę odegrało także osłabienie oddziaływania „miękkiej siły” UE na wschodzie spowodowane kryzysem strefy euro oraz renacjonalizacją polityk zagranicznych jej poszczególnych członków. To ostatnie było widoczne już od rozszerzenia z 2004 r., gdy strategie polityki Polski i państw bałtyckich wobec Rosji mocno rozeszły się ze wschodnioeuropejskimi interesami Niemiec. Wobec obecnego wstrzymania procesów demokratyzacyjnych w krajach b. ZSRR i koncentracji uwagi UE na uratowaniu projektu integracyjnego za cenę jego dalszego rozszerzenia, w debacie na temat stosunków międzynarodowych powrócił koncept Europy Środkowej, który znów ma sporo cech projektu tożsamościowego. Zgodnie z nim granica regionu na południu zaczyna się na zachód od Adrianopola, biegnie dalej Prutem, Bugiem i Niemnem, by na północy zakończyć się przy ujściu Narwy do Zatoki Fińskiej. Poza nią pozostaje dawna radziecka (historycznie ruska i prawosławna) Europa Wschodnia, a także tzw. Bałkany Zachodnie, region siedmiu państw narodowych na terytorium dawnej Jugosławii i Albania. Ten ostatni pozostaje „na zewnątrz", jednak tylko formalnie - wobec niego UE robi jednak wiele, aby spełnić obietnice akcesyjne.

Przemiany ostatniego dwudziestolecia w krajach Europy Środkowej (Środkowo-Wschodniej) dobitnie potwierdziły przekonanie, iż w regionie po upadku komunizmu nie stworzono innego modelu transformacyjnego niż oparty na homogenicznej tożsamości narodowej, zbudowanej głównie 
na heroiczno-martyrologicznych interpretacjach dziejów narodowych. Kraje bałtyckie osiągnęły ten efekt, stosując faktycznie zasadę solidarności etnicznej, powstrzymującej przed udziałem w rządach ugrupowania reprezentujące mniejszości narodowe ${ }^{50}$, Chorwacja natomiast po radykalnym zmniejszeniu liczebności mniejszości serbskiej na swoim terytorium w wyniku odzyskania manu militari Krajiny i Slawonii w $1995 \mathrm{r}$. W Serbii proces konsolidacji demokracji i przygotowań do integracji z UE posunął się znacznie dalej po tym, jak faktycznie utraciła ona kontrolę nad Kosowem (choć to ostatnie stało się wbrew większości jej opinii publicznej). Przypadkiem potwierdzającym związek między modelem modernizacji w tej części świata a unifikacją narodową jest także Bośnia i Hercegowina, państwo federacyjne, którego mieszkańcy nie wytworzyli wspólnego projektu mimo osiemnastu już lat asysty wspólnoty międzynarodowej w procesie pokojowym (od 1995 r.). Jeszcze inny kazus, niezaprzeczający wszakże wskazanej prawidłowości, stanowi Ukraina, gdzie walka orientacji politycznych reprezentujących dwa przeciwstawne i wzajemnie wykluczające się modele tożsamości narodowej w ostatniej dekadzie doprowadziła niemal do blokady postępów procesu transformacyjnego.

Mimo tego, że ponowoczesne wyzwanie globalizacji kultury oraz indywidualizacji tożsamości czyni Masarykową refleksję nad losem „małego narodu" nie mniej aktualną niż przed stuleciem, narody Europy Środkowej (Środkowo-Wschodniej) raczej nie podejmują wysiłków na rzecz wspólnego wspierania regionalnej specyfiki kulturowej. Wyzwania, jakie przed nimi stoją, są nadal w dużej mierze inne niż te, które niepokoją opinię publiczną krajów Europy Zachodniej. Nie ma tu dużych społeczności imigracyjnych, nie ma zatem poczucia zagrożenia, iż wobec niepowodzeń polityki wielokulturowości narastające różnice wartości i stylów życia rozsadzą fundamenty ładu społecznego i prawnego. Jednocześnie jednak narody regionu nie mają poczucia bycia dziedzicami kultur o zasięgu światowym, czy przynajmniej takich, które cieszą się światowym prestiżem z racji swych osiągnięć cywilizacyjnych. Nadal, mimo upływu czterdziestu lat od momentu, w którym przywołani historycy amerykańscy powzięli zamiar przybliżenia światu ich historii, nie są one szerzej znane i borykają się z problemem ignorancji przyczyniającej się do kształtowania negatywnych sądów na ich temat (jak choćby osławione „polskie obozy zagłady"). Poczucie zagrożenia zanikiem kultur o niewielkim zasięgu terytorialnym i liczbowym, a w konsekwencji różnorodności kulturowej całego regionu, towarzyszy niewątpliwie opinii publicznej tutejszych

${ }^{50}$ Pierwszym sygnałem zmiany tej zasady jest wejście Akcji Wyborczej Polaków na Litwie do koalicji rządowej po wyborach parlamentarnych w październiku 2012 r. 
narodów, uzewnętrznia się jednak w sposób wynikający z mylnej lokalizacji jego źródła - we wrogości do „historycznych wrogów” (np. odrodzenie syndromu trianońskiego na Węgrzech). Elity tych narodów nadal realizują strategię walki o wizerunek międzynarodowy głównie w pojedynkę. Wśród znacznej części z nich utrzymuje się przekonanie, że im silniejsza konsolidacja tożsamościowa, budowana w dużej mierze w oparciu o kształtowanie pamięci o własnych racjach w historycznych konfliktach z sąsiadami, tym większe szanse przetrwania kultury i zdobycia szacunku przez państwo na arenie międzynarodowej.

Europę Środkową (Środkowo-Wschodnią) w pierwszej dekadzie XXI w. w skali światowej wyróżniała przede wszystkim obsesja pamięci. Im bardziej kraje do niej należące spoglądały w przyszłość, tym bardziej doświadczały poczucia niepewności i gwarancji przetrwania szukały w przeszłości. Towarzyszyło temu przekonanie, iż i podmiotem, i przedmiotem pamięci jest naród, natomiast pamięć jednostek i znajomość historii transnarodowej mają sens tylko o tyle, o ile „od dołu” lub „od góry” wzmacniają interpretację losów narodowych. Punktem odniesienia tej pamięci pozostawały wydarzenia lat 1939-1989 (zatem okresu, w czasie którego dzieliły one podobne doświadczenia, ale nie decydowały o własnym losie). Niemal wszystkie kraje w Europie, które przeszły w tym czasie przez rządy dwu systemów totalitarnych, w pierwszej dekadzie XXI w. stoczyły wewnętrzne i zewnętrzne „wojny o pamięć” (z reguły te dwa rodzaje konfliktów nakładały się na siebie, ale nie wszędzie z tak dezintegrującymi skutkami, jak w latach 2005-2010 na Ukrainie). Dotyczyło to także Niemiec, które po rozpadzie bloku radzieckiego musiały dokonać reintegracji b. NRD oraz „rozliczyć" się ze swymi wschodnimi sąsiadami z wydarzeń II wojny światowej (w tym sensie kraj ten należy do regionu, a sam termin „polityka wobec pamięci” jest niemieckiego pochodzenia) ${ }^{51}$. Podobnie zażarte „boje o historię" nastąpiły ostatnio także w Hiszpanii, jedynym kraju zachodniej części kontynentu, który w latach 1936-1939 padł ofiarą ideologicznej wojny domowej. Sposób wyjścia Hiszpanów z tego konfliktu - wprowadzona pod rządami lewicy w 2007 r. ustawa uznająca jednostkę za podmiot pamięci i zdejmująca z państwa odpowiedzialność za kształtowanie jednej pamięci narodowej ${ }^{52}$ - pokazuje, że pod względem stosunku do historii najnowszej region Europy Środkowej (Środkowo-Wschodniej) istnieje nadal i obejmuje obszar na wschód od dawnej żelaznej kurtyny.

${ }^{51}$ A. Wolff-Powęska, Pamięć - brzemię i uwolnienie. Niemcy wobec nazistowskiej przeszłości (1945-2010), Poznań 2011, s. 66-69.

${ }^{52}$ Zob. O. Shevel, The politics of memory in a divided society: a comparison of post-Franco Spain and post-Soviet Ukraine, „Slavic Review” 70, 2011, 1, s. 137-164. 
$*$

Paradoks współczesnej sytuacji Europy Środkowej (Środkowo-Wschodniej) polega na tym, że w XIX w. powstała ona dzięki otwartym na siebie nawzajem ideologiom narodowym, a dziś - gdy wreszcie może cieszyć się jednocześnie wolnością i perspektywą dobrobytu - podmywa ją bezwzględnie prowadzona polityka narodowa. Wydaje się, iż to, czy region ten ma szanse na przyszłe życie, czy pozostanie tylko przestrzenią powrotów do przeszłości, które podsycają antagonizmy między krajami wchodzącymi w jego skład, a także między nimi i dawnymi centrami imperialnymi, najbardziej zależy od samych historyków. Unikalność tego regionu w skali światowej polega na tym, że stwarza on wyjątkowe warunki do pokazywania wielokulturowego i ponadnarodowego wymiaru przeszłości - ze względu na dużą zmienność granic i brak ciągłości jednostek politycznych, duże ruchy migracyjne, różnorodność religijną, a jednocześnie dużą obfitość źródeł pisanych, która liczbą ustępuje tylko Europie Zachodniej. Warunkiem odbudowy takiego „potencjału” przeszłości Europy Środkowej (Środkowo-Wschodniej) jest jednak odsunięcie historii od narodowej polityki, a także odejście od sposobu przedstawiania jej dziejów, który służy projektom tożsamościowym opartym na negatywnych punktach odniesienia. W tym celu historię Europy na wschód od Łaby, Alp i Adriatyku trzeba „wyjąć” spod władzy narracji narodowych i interpretacji regionalnych polegających na podkreślaniu wielowiekowej koherencji wewnętrznej i pomijaniu niespójności, a niekiedy także zacieraniu wpływów Wschodu i podkreślaniu pierwszeństwa historycznego w stosunku do osiągnięć Zachodu. Zarazem należy „otworzyć" do niej dostęp badaczom doceniającym jej różnorodność i dostrzegającym w przeszłości taką samą bezradność ludzi wobec przyszłości i tak samo niepewny, czy wręcz przypadkowy charakter ich działań, jak te uczucia i działania, które towarzyszą dziś nam samym. Zmiana ta nie powinna pozostać bez wpływu na politykę (nie tylko tę, którą prowadzi się dziś wobec pamięci). Powinna przyczynić się do uświadomienia sobie „małości” tutejszych narodów we współczesnym świecie i skłonić do refleksji nad tym, jak adaptować do dzisiejszych czasów projekty współpracy międzynarodowej stanowiące o unikalności dziejów tego regionu. 


\section{Central Europe (East-Central Europe) or Extolling Diversity and Comparatistics}

This essay is, on the one hand, historiographic and, on the other hand, politological. In the first part the author analysed ways of using the terms: "Central Europe" and "East-Central Europe" in contemporary multi-volume syntheses of the region's history, as a rule spanning from the ninth-tenth century to the end the last century. In the second part he shared reflections on the shaping of the common, supra-national identity of Central (East-Central) Europe from the middle of the nineteenth century and the question why at present it is not expressed in the existence of a regional political or economic organisation uniting the interests of its members.

The author expressed the conviction that in reference to the past it is possible to apply the concept: "Central (East-Central) Europe" albeit in each epoch phenomena that granted this region its specificity represented a different intensity and range; hence, the boundaries of the region in question were frequently subjected to changes. The second postulate formulated by the author and addressed to historians is the avoidance of identity narration based on a negative reference to "outer" objects. In syntheses of the region such a point of reference is to this very day Russia, treated, predominantly in Polish historiography, as a "civilisation" that does not meet the standards of the West.

The author believes that it is possible to speak about a more permanent East-Central Europe only starting from the mid-nineteenth century, when there came being an outline of the idea of solidarity in the struggle conducted by nations against empires. The experiences of the twentieth century - symbolised by the events of 1918, 1945 and 1989 - also granted an increasing number of joint features to the region from Estonia to Albania and contributed to the establishment of regional supra-national identity.

The end of the "brief twentieth century" and the post-1989 achievement by the states of the region of membership in Western structures (NATO,EU) contributed to weakening the feeling of regional bonds. Such contemporary phenomena as: the renationalisation of foreign policies, obsessive memories of events from the 1939-1989 period, growing tension with neighbouring countries and concern about the identity of the "small" nations in an epoch of globalisation are the reason why the pro-community potential of East-Central Europe, moulded in the previous half a century, is waning.

Translated by Alekandra Rodzińska-Chojnowska 